\title{
Geomicrobium halophilum gen. nov., sp. nov., a moderately halophilic and alkaliphilic bacterium isolated from soil
}

Correspondence
Akinobu Echigo
dc0400017@toyonet.toyo.ac.jp

\author{
Akinobu Echigo, ${ }^{1}$ Hiroaki Minegishi, ${ }^{1}$ Toru Mizuki, ${ }^{1,2}$ Masahiro Kamekura ${ }^{3}$ \\ and Ron Usami ${ }^{1,2,4}$
${ }^{1}$ Bio-Nano Electronics Research Centre, Toyo University, 2100 Kujirai, Kawagoe, Saitama 350-8585, Japan
${ }^{2}$ Faculty of Engineering, Toyo University, 2100 Kujirai, Kawagoe, Saitama 350-8585, Japan
${ }^{3}$ Halophiles Research Institute, 677-1 Shimizu, Noda, Chiba 278-0043, Japan
${ }^{4}$ Graduate School of Interdisciplinary New Science, Toyo University, 2100 Kujirai, Kawagoe, \\ Saitama 350-8585, Japan
}

Halophilic micro-organisms require $\mathrm{NaCl}$ for growth, while alkaliphilic micro-organisms use $\mathrm{Na}^{+}$for the adjustment of intracellular $\mathrm{pH}$, solute transport and flagella rotation (Krulwich et al., 1982). Thus, both depend on $\mathrm{NaCl}$ for growth. A number of haloalkaliphilic species that belong to the genus Bacillus and related genera, such as Alkalibacillus, Gracilibacillus and Halobacillus, have been isolated from various saline environments (Fritze, 1996; Jeon et al., 2005; Romano et al., 2005; Spring et al., 1996; Wainø et al., 1999). In recent years, however, some haloalkaliphilic strains such as Alkalibacillus silvisoli (Usami et al., 2007), Bacillus oshimensis (Yumoto et al., 2005) and Halalkalibacillus halophilus (Echigo et al., 2007) have been isolated from ordinary field soils in Japan. In the

The GenBank/EMBL/DDBJ accession numbers for the 16S rRNA gene sequences of strains $B 1^{\top}$ and HN5 are AB449106 and AB449107, respectively.

Scanning electron micrographs of strains $\mathrm{BH}^{\top}$ and $\mathrm{HN} 5$ and a maximum-likelihood tree showing the relationships of $\mathrm{BH}^{\top}, \mathrm{HN} 5$ and other related strains are available with the online version of this paper. present study, we report on the isolation and characterization of moderately haloalkaliphilic strains $\mathrm{BH}^{\mathrm{T}}$ and HN5 from ordinary soils in Japan. We suggest that these strains represent a novel species in a new genus.

Soil samples were taken from a forest in Kawagoe City and a garden in Kawasaki City, Japan. The two sampling sites were about 50 and $5 \mathrm{~km}$ from the seashore, respectively. Soil samples were taken from near trees or plants. The $\mathrm{pH}$ values of the soil extracts were slightly acidic, pH 5.0-6.0. The isolation medium (JCM medium No. 611, with $20 \%$ $\mathrm{NaCl})$ contained the following $\left(\mathrm{l}^{-1}\right): 5.0 \mathrm{~g}$ Casamino acids (Difco), $5.0 \mathrm{~g}$ yeast extract (Difco), $1.0 \mathrm{~g}$ sodium glutamate. $\mathrm{H}_{2} \mathrm{O}, 3.0 \mathrm{~g}$ trisodium citrate. $2 \mathrm{H}_{2} \mathrm{O}, 2.0 \mathrm{~g} \mathrm{KCl}$, $0.2 \mathrm{~g} \mathrm{MgSO}_{4} .7 \mathrm{H}_{2} \mathrm{O}, 36 \mathrm{mg} \mathrm{FeCl} \cdot 4 \mathrm{H}_{2} \mathrm{O}, 200.0 \mathrm{~g}(3.4 \mathrm{M})$ $\mathrm{NaCl}$ and $20.0 \mathrm{~g}$ Bacto agar (Difco) (pH 7.2). After autoclaving, the $\mathrm{pH}$ was adjusted to 9.5 by adding precalculated amounts of sterile $10 \%$ (w/v) $\mathrm{Na}_{2} \mathrm{CO}_{3}$ solution. About $0.5 \mathrm{~g}$ of the soil samples was placed on agar plates, spread with a spatula, and incubated at $37^{\circ} \mathrm{C}$ for 3 weeks in a plastic bag to prevent desiccation. Colonies were picked up, transferred to fresh agar plates, and pure 
cultures were obtained by plating serial dilutions and repeated transfers on agar plates. After partial sequencing (about 500 bp of the $5^{\prime}$-end) of PCR-amplified 16S rRNA genes of 29 isolates, two strains, $\mathrm{BH}^{\mathrm{T}}$ isolated from a forest soil in Toyo University, Kawagoe City, and strain HN5 isolated from a garden soil in Kawasaki City, were selected for further characterization. The 16S rRNA gene sequence similarity between strains $\mathrm{BH}^{\mathrm{T}}$ and $\mathrm{HN} 5$ (1479 bp) was $99.9 \%$. In addition, DNA-DNA hybridization assessed by the fluorometric method of Ezaki et al. (1989) showed high levels of relatedness (88 and 85\%, reciprocally), suggesting that these two strains should be classified within the same species.

Growth characteristics, production of acid from carbohydrates and sensitivity to antimicrobial agents were determined as described previously (Echigo et al., 2007; Usami et al., 2007). All phenotypic tests were carried out in JCM medium No. 611 with $10 \% \mathrm{NaCl}$ and incubated at $37^{\circ} \mathrm{C}$. Cell morphology was studied using a phase-contrast microscope (ZEISS; Axiovert 135) and a scanning electron microscope (JEOL; JSM-7400F). Endospore formation by strains $\mathrm{BH} 1^{\mathrm{T}}$ and $\mathrm{HN} 5$ cultivated under various conditions [30 and $37^{\circ} \mathrm{C}$ for 1,2 and 3 days in/on liquid and agar medium (JCM No. 611) with 5, 10, 15, 20 and $25 \%(\mathrm{w} / \mathrm{v})$ $\mathrm{NaCl}, \mathrm{pH} 7.0,8.0,9.0,9.5$ and 10.0] was determined by spore-staining according to the method of Wirtz-Conklin (Murray et al., 1999) or by heating cultures at 70,80 or $90{ }^{\circ} \mathrm{C}$ for $30 \mathrm{~min}$. Alkaliphilic, moderately halophilic bacteria Alkalibacillus haloalkaliphilus JCM $12303^{\mathrm{T}}$ and Halalkalibacillus halophilus JCM $14192^{\mathrm{T}}$ were used as positive control strains. Colonies of strains $\mathrm{BH}^{\mathrm{T}}$ and HN5 formed on agar plates were approximately $1.0-1.5 \mathrm{~mm}$ in diameter, brown, opaque and stained the surrounding agar brown. Cells of strain $\mathrm{BH}^{\mathrm{T}}$ and HN5 were non-motile, bean-shaped, approximately $0.5-0.7 \times 1.0-1.2 \mu \mathrm{m}$ and formed irregular clusters with 2-20 cells (Supplementary Fig. S1 in IJSEM Online). Both strains were Gram-positive. Spores were not observed by staining or by phase-contrast microscopy. After the heat treatment, only very few colonies $\left(0-3\right.$ out of $2-3 \times 10^{4}$ cells in 20 experiments) were obtained. Growth characteristics were determined under the following conditions with JCM liquid medium No. 611 as basal medium: $\mathrm{NaCl}$ concentrations of $0,1,2,3,4$ and $5-30 \%(\mathrm{w} / \mathrm{v})$ at $5 \%(\mathrm{w} / \mathrm{v})$ intervals, $\mathrm{pH} 9.5,37{ }^{\circ} \mathrm{C}$; $\mathrm{pH}$ of $5.0-11.0$ at 0.5 intervals, adjusted by $10 \%(\mathrm{w} / \mathrm{v}) \mathrm{H}_{2} \mathrm{SO}_{4}$ solution or $10 \%(\mathrm{w} / \mathrm{v})$ $\mathrm{KOH}$ solution, $10 \%(\mathrm{w} / \mathrm{v}) \mathrm{NaCl}, 37^{\circ} \mathrm{C}$; and temperature of $10-70{ }^{\circ} \mathrm{C}$ at $10{ }^{\circ} \mathrm{C}$ intervals, $10 \%(\mathrm{w} / \mathrm{v}) \mathrm{NaCl}, \mathrm{pH} 9.5$. Strains $\mathrm{BH}^{\mathrm{T}}$ and $\mathrm{HN} 5$ grew in $5-25 \%(\mathrm{w} / \mathrm{v}) \mathrm{NaCl}$, with optimum growth at $10-15 \%(\mathrm{w} / \mathrm{v}) \mathrm{NaCl}$. No growth was observed in media with $0-4 \% \mathrm{NaCl}$. Viable cell numbers did not decrease when cells grown in $10 \% \mathrm{NaCl}$ medium were suspended in distilled water for $1 \mathrm{~h}$ at room temperature. Growth occurred within the $\mathrm{pH}$ range 6.0-10.0, with optimum growth at $\mathrm{pH} 8.5-9.0$. The $\mathrm{pH}$ values of media adjusted to $\mathrm{pH} 6.0$ and 10.0 were 6.1 and 6.3 , and 9.7 and 9.4, at early-exponential and stationary phases, respectively. The temperature range for growth was $20-40{ }^{\circ} \mathrm{C}$, with optimum growth at $30{ }^{\circ} \mathrm{C}$. Anaerobic growth was not observed in an anaerobic jar after incubation for 7 days at $37{ }^{\circ} \mathrm{C}$. Sole carbon source utilization was tested in modified JCM liquid medium No. 611, without Casamino acids and yeast extract. Strains $\mathrm{BH} 1^{\mathrm{T}}$ and HN5 showed almost no growth in this medium. They utilized cellobiose, glycerol, lactose, D-mannitol, raffinose, trehalose, D-sorbitol and sucrose as sole carbon sources, but did not use L-arabinose, D-fructose, D-galactose, Dglucose, maltose, D-mannose, ribose or D-xylose. Strain $\mathrm{BH} 1^{\mathrm{T}}$ produced acid from D-glucose, glycerol, D-sorbitol and sucrose, but not from L-arabinose, cellobiose, D-fructose, D-galactose, lactose, maltose, D-mannitol, D-mannose, raffinose, ribose, trehalose or D-xylose. Strain HN5 produced acid from D-fructose, D-galactose, D-glucose, glycerol and sucrose, but not from L-arabinose, cellobiose, lactose, maltose, D-mannitol, D-mannose, raffinose, ribose, D-sorbitol, trehalose or D-xylose.

Tests for catalase, oxidase and decarboxylase activities, starch, pullulan, casein, gelatin, Tween 80 , tributyrin, DNA, hippurate, aesculin, urea, tyrosine, xanthine and hypoxanthine hydrolysis, indole and $\mathrm{H}_{2} \mathrm{~S}$ production and reduction of nitrate were performed according to the standard or modified procedures of Smibert \& Krieg (1981, 1994), Oren et al. (1997) and Schlesner et al. (2001). Strains $\mathrm{BH}^{\mathrm{T}}$ and HN5 were catalase-, oxidase- and ornithine decarboxylase-positive, but arginine decarboxylase- and lysine decarboxylase-negative. Casein and gelatin were hydrolysed, but starch, pullulan, Tween 80 , tributyrin, DNA, hippurate, aesculin, urea, tyrosine, xanthine and hypoxanthine were not hydrolysed. Indole and $\mathrm{H}_{2} \mathrm{~S}$ were not produced from tryptophan or thiosulfate. Reduction of nitrate was not detected by using the sulfanilic acid and $\alpha$ naphthylamine reagent, and formation of gas from nitrate was not detected using Durham tubes under anaerobic conditions.

HPLC analysis of isoprenoid quinones, GC/MS analysis of fatty acid methyl esters and TLC analysis of polar lipids were performed according to the modified procedures of Minnikin et al. (1984), Tamaoka (1986) and Komagata \& Suzuki (1987). Strains $\mathrm{BH}^{\mathrm{T}}$ and HN5 were cultivated at $30{ }^{\circ} \mathrm{C}$ for 3 days in JCM liquid medium No. 611. The isoprenoid quinones of strains $\mathrm{BH}^{\mathrm{T}}$ and $\mathrm{HN} 5$ were menaquinone-7 (MK-7) and menaquinone-6 (MK-6) with ratios of $71: 20$ and $64: 18$, respectively. No other significant peaks were observed. The phospholipids of strains $\mathrm{BH} 1^{\mathrm{T}}$ and HN5 were diphosphatidylglycerol and phosphatidylglycerol. The cellular fatty acid profiles of strains $\mathrm{BH}^{\mathrm{T}}$ and $\mathrm{HN} 5$ were characterized by saturated branched fatty acids such as $\mathrm{i}-\mathrm{C}_{15: 0}, \mathrm{i}-\mathrm{C}_{17: 0}$ and $\mathrm{i}-\mathrm{C}_{18: 0}$ (42:24:10 and 39:30:8, respectively).

Preparation of peptidoglycan and determination of its structure were performed according to the modified procedures of Schleifer \& Kandler (1972), Schleifer (1985) and Schlesner et al. (2001) as described previously 
(Echigo et al., 2007; Usami et al., 2007). The resulting fingerprints were compared with those from known peptidoglycan structures. Strains $\mathrm{BH}^{\mathrm{T}}$ and $\mathrm{HN} 5$ possessed A $1 \gamma$, meso-diaminopimelic acid-type murein.

Total DNA was extracted by the method of Saito \& Miura (1963). The DNA G $+\mathrm{C}$ content of strains $\mathrm{BH}^{\mathrm{T}}$ and $\mathrm{HN} 5$, determined by the HPLC method of Tamaoka \& Komagata (1984), was 45 and $46 \mathrm{~mol} \%$, respectively. The $16 \mathrm{~S}$ rRNA genes were amplified by PCR with the following forward and reverse primers: 5'-AGAGTTTGATCCTGGCTCAG-3' (positions 8-27 according to Escherichia coli numbering) and 5'-GGCTACCTTGTTACGACTT-3' (positions 15101492). The amplified DNA was cloned using the TA Cloning kit (Invitrogen) and sequenced using the $\mathrm{ABI}$ PRISM BigDye Terminator v3.1 Cycle Sequencing kits (Applied Biosystems) with the primers 5'-GGAAACAGCTATGACCATG-3' (vector side), 5'-GACTACCAGGGTATCTAATC-3' (positions 805-786), 5'-AGGGTTGCGCTCGTTG-3' (positions 1115-1100) and 5'-GTAAAACGACGGCCAGT-3' (vector side) on the ABI PRISM 310 Genetic Analyzer (Applied Biosystems). The 16S rRNA gene sequences of strains $\mathrm{BH}^{\mathrm{T}}$ and HN5 (1479 bp) were $99.9 \%$ similar, but showed very low similarities with those of any recognized species. The $16 \mathrm{~S}$ rRNA gene sequence of strain $\mathrm{BH}^{\mathrm{T}}$ was most closely related to that of Bacillus salarius [ $90.2 \%$ by the FASTA system (Pearson \& Lipman, 1988; Lipman \& Pearson, 1985) and $89.9 \%$ by the EzTaxon server 2.0 (Chun et al., 2007)], Bacillus pseudofirmus $(90.0 \%$ and $90.3 \%)$, Planomicrobium okeanokoites ( $89.3 \%$ and $90.1 \%)$, Bacillus akibai (89.3\% and $89.9 \%)$, Marinococcus halophilus ( $88.9 \%$ by FASTA) and Sinobaca qinghaiensis ( $88.1 \%$ by FASTA). These values are sufficient to permit classification of these strains as a different genus (Ludwig et al., 1998). The sequences of related strains retrieved from the DNA Data Bank of Japan (Miyazaki et al., 2003) were aligned using CLUSTAL_X 2.0.9 (Larkin et al., 2007). The length of the $16 \mathrm{~S}$ rRNA gene sequences used in the phylogenetic analysis ranged from $1380 \mathrm{bp}$ (B. salarius; AY667494) to $1553 \mathrm{bp}$ (Bacillus subtilis; X60646). The neighbour-joining tree was reconstructed using the method of Saitou \& Nei (1987), and was evaluated by bootstrap sampling methods (Felsenstein, 1985), based on 1000 replicates. Maximum-likelihood analyses were performed with RAxML 7.0.4 using the GTR $+\Gamma$ model (Stamatakis et al., 2005). Support values for the maximum-likelihood tree were obtained by bootstrapping (100 replicates) using CONSENSE in PHYLIP. The neighbour-joining tree (Fig. 1) and maximum-likelihood tree (Supplementary Fig. S2) showed that strains $\mathrm{BH}^{\mathrm{T}}$ and HN5 were closely related to $M$. halophilus, B. salarius, S. qinghaiensis and other Bacillus species but formed another distinctly separate cluster.

Phenotypic properties of strains $\mathrm{BH} 1^{\mathrm{T}}$ and $\mathrm{HN} 5$ supported the view that the isolates were distinguishable from the most closely related species, M. halophilus DSM $20408^{\mathrm{T}}$ (Hao et al., 1984), B. salarius DSM $16461^{\mathrm{T}}$ (Lim et al., 2006) and S. qinghaiensis DSM $17008^{\mathrm{T}}$ (Li et al., 2006) (Table 1). Cells of strains $\mathrm{BH}^{\mathrm{T}}$ and HN5 were bean- shaped and formed irregular clusters, whereas B. salarius was single rod-shaped and M. halophilus and S. qinghaiensis were in single spherical form. The predominant isoprenoid quinones of strains $\mathrm{BH}^{\mathrm{T}}$ and $\mathrm{HN} 5$ were MK-7 and MK-6, whereas MK-7 was predominant in B. salarius and $M$. halophilus, and MK-5 in S. qinghaiensis. The major cellular fatty acid of strains $\mathrm{BH}^{\mathrm{T}}$ and $\mathrm{HN} 5$ was $\mathrm{i}-\mathrm{C}_{15: 0}$, whereas the three most closely related species possess ai- $\mathrm{C}_{15: 0}$. The other selected characteristics that distinguish strains $\mathrm{BH}^{\mathrm{T}}$ and HN5 from the three most closely related species are shown in Table 1 . The above phylogenetic and phenotypic characteristics indicated that strains $\mathrm{BH}^{\mathrm{T}}$ and $\mathrm{HN} 5$ represent a novel species in a new genus, for which the name Geomicrobium halophilum gen. nov., sp. nov. is proposed.

\section{Description of Geomicrobium gen. nov.}

Geomicrobium (Ge.o.mi.cro'bi.um. Gr. n. ge soil; N.L. neut. n. microbium a microbe; N.L. neut. n. Geomicrobium a microbe from soil).

Cells are non-motile, Gram-positive, non-spore-forming, bean-shaped, approximately $0.5-0.7 \times 1.0-1.2 \mu \mathrm{m}$ and form irregular clusters with 2-20 cells. Cell walls contain A1 $\gamma$, meso-diaminopimelic acid-type murein. No growth occurs in media without $\mathrm{NaCl}$. Alkaliphilic, mesophilic, aerobic and halophilic. Catalase- and oxidase-positive. The DNA G $+\mathrm{C}$ content is $45 \mathrm{~mol} \%$. The predominant isoprenoid quinones are MK-7 and MK-6. Major cellular fatty acids are $\mathrm{i}-\mathrm{C}_{15: 0}, \mathrm{i}-\mathrm{C}_{17: 0}$ and $\mathrm{i}-\mathrm{C}_{18: 0}$. The type species is Geomicrobium halophilum.

\section{Description of Geomicrobium halophilum sp. nov.}

Geomicrobium halophilum (ha.lo.phi'lum. Gr. n. hals halos salt; Gr. adj. philos loving; N.L. neut. adj. halophilum salt-loving).

Exhibits the following characteristics in addition to those given in the genus description. Colonies formed on agar are approximately $1.0-1.5 \mathrm{~mm}$ in diameter, brown, opaque and stained the surrounding agar brown. Spore formation is not detected. Growth occurs in 5-25\% (w/v) NaCl, with maximum growth at $10-15 \%(\mathrm{w} / \mathrm{v}) \mathrm{NaCl}$. No growth occurs in the absence of $\mathrm{NaCl}$, but cells do not die. Growth occurs at $\mathrm{pH} 6.0-10.0$, with optimum growth at $\mathrm{pH}$ 8.5-9.0. Temperature range for growth is $20-40{ }^{\circ} \mathrm{C}$, with optimum growth at $30{ }^{\circ} \mathrm{C}$. Cellobiose, glycerol, lactose, Dmannitol, raffinose, trehalose, D-sorbitol and sucrose can be utilized as sole carbon sources; L-arabinose, D-fructose, D-galactose, D-glucose, maltose, D-mannose, ribose and Dxylose cannot be utilized. Acid is produced from D-glucose, glycerol, D-sorbitol and sucrose, but not from L-arabinose, cellobiose, D-fructose, D-galactose, lactose, maltose, Dmannitol, D-mannose, raffinose, ribose, trehalose or Dxylose. Sensitive to ampicillin ( $50 \mu \mathrm{g}$ per disc), bacitracin $(25 \mu \mathrm{g}$ per disc), chloramphenicol $(25 \mu \mathrm{g}$ per disc), erythromycin $(25 \mu \mathrm{g}$ per disc), gentamicin $(50 \mu \mathrm{g}$ per 


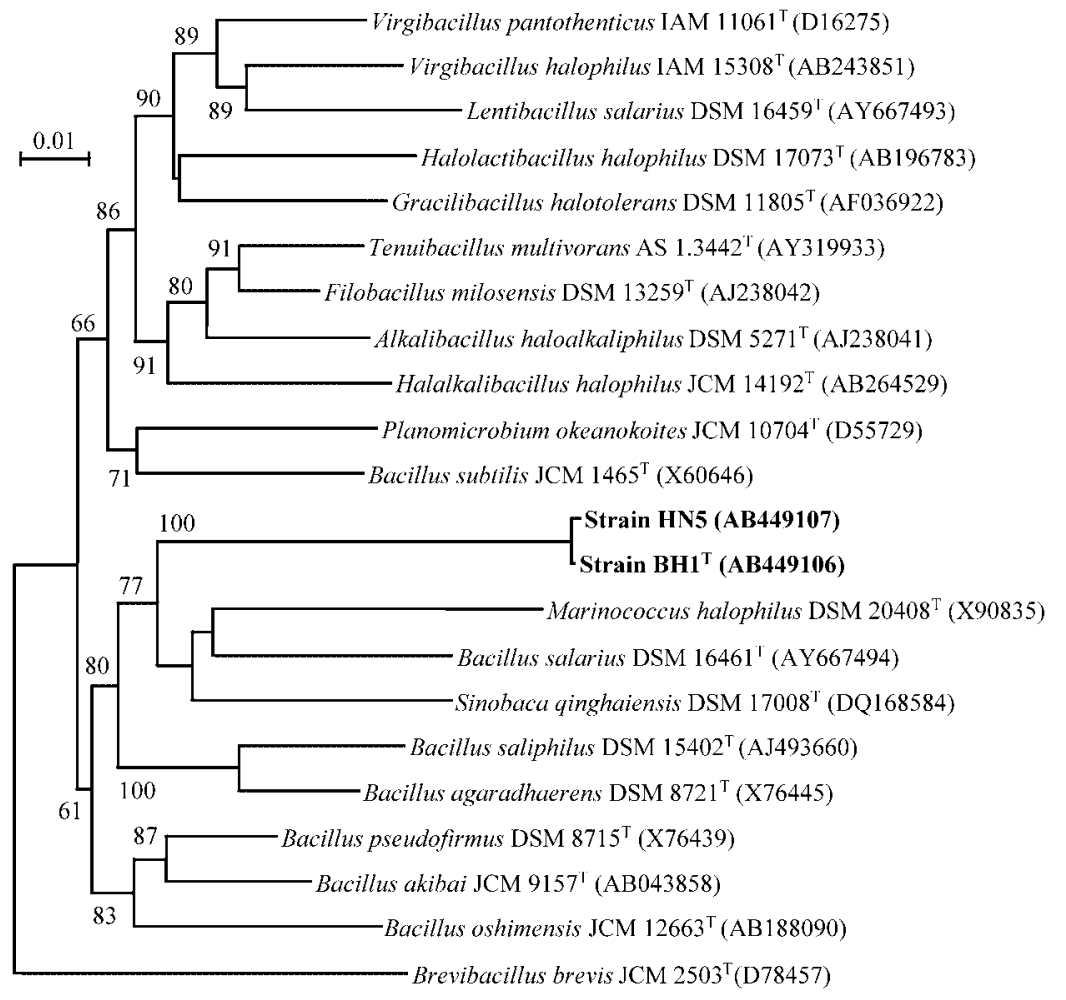

Fig. 1. Neighbour-joining tree based on $16 \mathrm{~S}$ rRNA gene sequences showing the phylogenetic relationships of $\mathrm{BH}^{\top}{ }^{\top}, \mathrm{HN} 5$ and other related strains. Bootstrap percentage is based on 1000 replicates; those greater than $60 \%$ are shown. Brevibacillus brevis JCM $2503^{\top}$ (D78457) was used as an outgroup. Scale bar, 0.01 changes per nucleotide position.

Table 1. Differential characteristics of strain $B H 1^{\top}, \mathrm{HN} 5$ and related taxa

Taxa: 1, strains BH1 ${ }^{\mathrm{T}} / \mathrm{HN} 5 ; 2$, Bacillus salarius DSM $16461^{\mathrm{T}} ; 3$, Marinococcus halophilus DSM $20408^{\mathrm{T}} ; 4$, Sinobaca qinghaiensis DSM $17008^{\mathrm{T}}$. Data from Hao et al. (1984), Li et al. (2006) and Lim et al. (2006). +, Positive; -, negative; ND, no data.

\begin{tabular}{|c|c|c|c|c|}
\hline Colonial pigmentation & Brown & Cream & Yellow-orange & Orange \\
\hline Cell morphology & Bean-shaped & Short rods & Cocci & Cocci \\
\hline Motility & - & - & + & + \\
\hline \multicolumn{5}{|l|}{ Acid production from: } \\
\hline L-Arabinose & - & + & ND & ND \\
\hline D-Fructose & $-1+$ & + & + & - \\
\hline Lactose & - & + & ND & ND \\
\hline Maltose & - & + & - & + \\
\hline D-Mannitol & - & + & - & + \\
\hline D-Mannose & - & + & ND & ND \\
\hline Ribose & - & + & $\mathrm{ND}$ & $\mathrm{ND}$ \\
\hline \multicolumn{5}{|l|}{ Hydrolysis of: } \\
\hline Starch & - & + & - & - \\
\hline Gelatin & + & ND & + & - \\
\hline Tween 80 & - & + & ND & ND \\
\hline Aesculin & - & + & + & ND \\
\hline $\mathrm{G}+\mathrm{C}$ content $(\mathrm{mol} \%)$ & $45 / 46$ & 43 & 46.4 & 47.0 \\
\hline Isoprenoid quinone & MK-7, MK-6 & MK-7 & MK-7 & MK-5 \\
\hline Major fatty acids & $\mathrm{i}-\mathrm{C}_{15: 0}, \mathrm{i}-\mathrm{C}_{17: 0}, \mathrm{i}-\mathrm{C}_{18: 0}$ & ai- $C_{15: 0}$, ai- $C_{17: 0}, i-C_{15: 0}, i-C_{16: 0}$ & ai- $C_{15: 0}$, ai $-C_{17: 0}, i-C_{16:}$ & ai $-C_{15: 0}$, ai $-C_{17: 0}$ \\
\hline
\end{tabular}


disc), novobiocin $(25 \mu \mathrm{g}$ per disc), penicillin $\mathrm{G}(25 \mu \mathrm{g}$ per disc), rifampicin $(50 \mu \mathrm{g}$ per disc), streptomycin $(100 \mu \mathrm{g}$ per disc), tetracycline (50 $\mu \mathrm{g}$ per disc) and vancomycin (25 $\mu \mathrm{g}$ per disc); resistant to anisomycin (50 $\mu \mathrm{g}$ per disc), kanamycin $(50 \mu \mathrm{g}$ per disc), neomycin $(25 \mu \mathrm{g}$ per disc $)$ and pravastatin $(50 \mu \mathrm{g}$ per disc).

Ornithine decarboxylase-positive, but arginine decarboxylase- and lysine decarboxylase-negative. Casein and gelatin are hydrolysed; starch, pullulan, Tween 80 , tributyrin, DNA, hippurate, aesculin, urea, tyrosine, xanthine and hypoxanthine are not hydrolysed. Indole and $\mathrm{H}_{2} \mathrm{~S}$ are not produced. Reduction of nitrate and gas formation are not observed. The phospholipids are diphosphatidylglycerol and phosphatidylglycerol.

The type strain is strain $\mathrm{BH}^{\mathrm{T}}\left(=\mathrm{JCM} \quad 15647^{\mathrm{T}}=\mathrm{DSM}\right.$ $21769^{\mathrm{T}}$ ), isolated from ordinary soil from a forest in a campus of Toyo University, Kawagoe City, Saitama Prefecture, Japan.

\section{References}

Chun, J., Lee, J.-H., Jung, Y., Kim, M., Kim, S., Kim, B. K. \& Lim, Y. W. (2007). EzTaxon: a web-based tool for the identification of prokaryotes based on $16 \mathrm{~S}$ ribosomal RNA gene sequences. Int J Syst Evol Microbiol 57, 2259-2261.

Echigo, A., Fukushima, T., Mizuki, T., Kamekura, M. \& Usami, R. (2007). Halalkalibacillus halophilus gen. nov., sp. nov., a new moderately halophilic and alkaliphilic bacterium isolated from a non-saline soil sample in Japan. Int J Syst Evol Microbiol 57, 10811085.

Ezaki, T., Hashimoto, Y. \& Yabuuchi, E. (1989). Fluorometric deoxyribonucleic acid-deoxyribonucleic acid hybridization in microdilution wells as an alternative to membrane filter hybridization in which radioisotopes are used to determine genetic relatedness among bacterial strains. Int J Syst Bacteriol 39, 224-229.

Felsenstein, J. (1985). Confidence limits on phylogenies: an approach using the bootstrap. Evolution 39, 783-791.

Fritze, D. (1996). Bacillus haloalkaliphilus sp. nov. Int J Syst Bacteriol 46, 98-101.

Hao, M. V., Kocur, M. \& Komagata, K. (1984). Marinococcus gen. nov., a new genus for motile cocci with meso-diaminopimelic acid in the cell wall; and Marinococcus albus sp. nov. and Marinococcus halophilus (Novitsky and Kushner) comb. nov. J Gen Appl Microbiol 30, 449459.

Jeon, C. O., Lim, J. M., Lee, J. M., Xu, L. H., Jiang, C. L. \& Kim, C. J. (2005). Reclassification of Bacillus haloalkaliphilus Fritze 1996 as Alkalibacillus haloalkaliphilus gen. nov., comb. nov. and the description of Alkalibacillus salilacus sp. nov., a novel halophilic bacterium isolated from a salt lake in China. Int J Syst Evol Microbiol 55, 1891-1896.

Komagata, K. \& Suzuki, K. (1987). Lipid and cell-wall analysis in bacterial systematics. Methods Microbiol 19, 161-207.

Krulwich, T. A., Guffanti, A. A., Bornstein, R. F. \& Hoffstein, J. (1982). A sodium requirement for growth, solute transport, and $\mathrm{pH}$ homeostasis in Bacillus firmus RAB. J Biol Chem 257, 1885-1889.

Larkin, M. A., Blackshields, G., Brown, N. P., Chenna, R., McGettigan, P. A., McWilliam, H., Valentin, F., Wallace, I. M., Wilm, A. \& other authors (2007). CLUSTAL $\mathrm{W}$ and CLUSTAL_X version 2.0. Bioinformatics 23, 2947-2948.
Li, W. J., Zhang, Y. Q., Schumann, P., Tian, X. P., Zhang, Y. Q., Xu, L. H. \& Jiang, C. L. (2006). Sinococcus qinghaiensis gen. nov., sp. nov., a novel member of the order Bacillales from a saline soil in China. Int J Syst Evol Microbiol 56, 1189-1192.

Lim, J. M., Jeon, C. O., Lee, S. M., Lee, J. C., Xu, L. H., Jiang, C. L. \& Kim, C. J. (2006). Bacillus salarius sp. nov., a halophilic, sporeforming bacterium isolated from a salt lake in China. Int J Syst Evol Microbiol 56, 373-377.

Lipman, D. J. \& Pearson, W. R. (1985). Rapid and sensitive protein similarity searches. Science 227, 1435-1441.

Ludwig, W., Strunk, O., Klugbauer, S., Klugbauer, N., Weizenegger, M., Neumaier, J., Bachleitner, M. \& Schleifer, K. H. (1998). Bacterial phylogeny based on comparative sequence analysis. Electrophoresis 19, 554-568.

Minnikin, D. E., O’Donnell, A. G., Goodfellow, M., Alderson, G., Athalye, M., Schaal, A. \& Parlett, J. H. (1984). An integrated procedure for the extraction of bacterial isoprenoid quinones and polar lipids. J Microbiol Methods 2, 233-241.

Miyazaki, S., Sugawara, H., Gojobori, T. \& Tateno, Y. (2003). DNA Data Bank of Japan (DDBJ) in XML. Nucleic Acids Res 31, 1316.

Murray, P. R., Baron, E. J., Pfaller, M. A., Tenover, F. C. \& Yolken, R. H. (1999). Manual of Clinical Microbiology, 7th edn. Washington DC: American Society for Microbiology.

Oren, A., Ventosa, A. \& Grant, W. D. (1997). Proposed minimal standards for description of new taxa in the order Halobacteriales. Int J Syst Bacteriol 47, 233-238.

Pearson, W. R. \& Lipman, D. J. (1988). Improved tools for biological sequence comparison. Proc Natl Acad Sci U S A 85, 24442448.

Romano, I., Lama, L., Nicolaus, B., Gambacorta, A. \& Giordano, A. (2005). Alkalibacillus filiformis sp. nov., isolated from a mineral pool in Campania, Italy. Int J Syst Evol Microbiol 55, 2395-2399.

Saito, H. \& Miura, K. (1963). Preparation of transforming deoxyribonucleic acid by phenol treatment. Biochim Biophys Acta 72, 619-629.

Saitou, N. \& Nei, M. (1987). The neighbour-joining methods: a new method for reconstructing phylogenetic trees. Mol Biol Evol 4, 406425.

Schleifer, K. H. (1985). Analysis of the chemical composition and primary structure of murein. Methods Microbiol 18, 123-156.

Schleifer, K. H. \& Kandler, O. (1972). Peptidoglycan types of bacterial cell walls and their taxonomic implications. Bacteriol Rev 36, 407477.

Schlesner, H., Lawson, P. A., Collins, M. D., Weiss, N., Wehmeyer, U., Völker, H. \& Thomm, M. (2001). Filobacillus milensis gen. nov., sp. nov., a new halophilic spore-forming bacterium with Orn-D-Glu-type peptidoglycan. Int J Syst Evol Microbiol 51, 425-431.

Smibert, R. M. \& Krieg, N. R. (1981). General characterization. In Manual of Methods for General Microbiology, pp. 409-443. Edited by P. Gerhardt, R. G. E. Murray, R. N. Costilow, E. W. Nester, W. A. Wood, N. R. Krieg \& G. B. Phillips. Washington, DC: American Society for Microbiology.

Smibert, R. M. \& Krieg, N. R. (1994). Phenotypic characterization. In Methods for General and Molecular Bacteriology, pp. 607-654. Edited by P. Gerhardt, R. G. E. Murray, W. A. Wood \& N. R. Krieg. Washington, DC: American Society for Microbiology.

Spring, S., Ludwig, W., Marquez, M. C., Ventosa, A. \& Schleifer, K. H. (1996). Halobacillus gen. nov., with description of Halobacillus litoralis sp. nov. and Halobacillus trueperi sp. nov., and transfer of Sporosarcina halophila to Halobacillus halophila comb. nov. Int J Syst Bacteriol 46, 492-496. 
Stamatakis, A., Ludwig, T. \& Meier, H. (2005). RAxML-III: a fast program for maximum likelihood-based inference of large phylogenetic trees. Bioinformatics 21, 456-463.

Tamaoka, J. (1986). Analysis of bacterial menaquinone mixtures by reverse-phase high-performance liquid chromatography. Methods Enzymol 123, 251-256.

Tamaoka, J. \& Komagata, K. (1984). Determination of DNA base composition by reversed-phase high-performance liquid chromatography. FEMS Microbiol Lett 25, 125-128.

Usami, R., Echigo, A., Fukushima, T., Mizuki, T., Yoshida, Y. \& Kamekura, M. (2007). Alkalibacillus silvisoli sp. nov., an alkaliphilic moderate halophile isolated from non-saline forest soil in Japan. Int $J$ Syst Evol Microbiol 57, 770-774.

Wainø, M., Tindall, B. J., Schumann, P. \& Ingvorsen, K. (1999). Gracilibacillus gen. nov., with description of Gracilibacillus halotolerans gen. nov., sp. nov.; transfer of Bacillus dipsosauri to Gracilibacillus dipsosauri comb. nov., and Bacillus salexigens to the genus Salibacillus gen. nov., as Salibacillus salexigens comb. nov. Int J Syst Bacteriol 49, 821-831.

Yumoto, I., Hirota, K., Goto, T., Nodasaka, Y. \& Nakajima, K. (2005). Bacillus oshimensis sp. nov., a moderately halophilic, non-motile alkaliphile. Int J Syst Evol Microbiol 55, 907-911. 